\title{
Physical activity in children and adolescents with type 1 diabetes and contemporary methods of its assessment
}

\author{
Aktywność fizyczna dzieci i młodzieży z cukrzycą typu 1 oraz współczesne metody jej oceny
}

\author{
Ewelina Czenczek-Lewandowska, Joanna Grzegorczyk, Artur Mazur
}

\author{
Medical Faculty, University of Rzeszow, Rzeszow, Poland
}

\begin{abstract}
Exercise is a determinant of people's well-being, and it contributes to the prevention and treatment of numerous diseases of affluence, e.g. diabetes and obesity. The rapid pace of economic development is affecting human functioning to such a degree that the need for physical activity, which has always been recognised as a biological and natural need, has been significantly reduced. Consequently, today public health related problems occurring globally are connected with the increasing incidence of cardiovascular, neoplastic, and metabolic diseases. These problems are manifested not only in adults, but they also increasingly affect children and adolescents worldwide. In the case of children with type 1 diabetes, physical activity is of particular importance because it contributes to the child's normal development and to positive effects of therapies. The paper discusses health-related benefits of physical activity in children and adolescents with type 1 diabetes, it presents recommendations related to physical activity published in Poland and abroad, and reviews contemporary methods of its assessment.
\end{abstract}

Key words:

physical activity, type 1 diabetes, children, adolescents.

\section{Streszczenie}

Ruch w życiu człowieka warunkuje zachowanie zdrowia oraz stanowi wartość profilaktyczną i leczniczą wielu chorób cywilizacyjnych, m.in. cukrzycy i otyłości. Współczesne szybkie tempo rozwoju gospodarczego i ekonomicznego wywarło tak silny wpływ na funkcjonowanie człowieka, że potrzeba ruchu, która od zawsze nazywana była biologiczną i naturalną, została znacznie ograniczona. W konsekwencji aktualne ogólnoświatowe problemy zdrowia publicznego koncentrują się na narastającej liczbie chorób sercowo-naczyniowych, nowotworowych i metabolicznych. Problemy te ujawniają się nie tylko u osób dorosłych, lecz zaczęły dotyczyć także coraz większej liczby dzieci i młodzieży na całym świecie. W przypadku dzieci chorych na cukrzycę typu 1 aktywność fizyczna nabiera szczególnego znaczenia, gdyż wpływa korzystnie na prawidłowy rozwój dziecka oraz efekty prowadzonej terapii. W pracy opisano korzyści zdrowotne płynące z aktywności fizycznej dzieci i młodzieży w cukrzycy typu 1, przedstawiono polskie i światowe rekomendacje dotyczące aktywności fizycznej, jak również omówiono współczesne metody jej oceny.

\section{Słowa kluczowe:}

aktywność fizyczna, cukrzyca typu 1, dzieci, młodzież. 


\section{Introduction}

For many years there were conflicting opinions related to physical activity in children and adolescents with type 1 diabetes. In order to minimise the risk of blood glucose fluctuations, in the past, patients with this condition were advised to avoid sports and high-intensity physical activity. Nowadays, however, exercise is recognised as an inseparable and integral element of diabetes management. In accordance with the current guidelines, any limitations that can reduce patients' activity should be eliminated [1]. Provided they are aware of their problem, children with well-controlled diabetes are able to perform high-intensity physical activity, just like their healthy peers. In most patients, diabetes is not a contraindication for doings sports, even at a professional level. A good example is Gary Hall, an American swimmer who won five gold medals during the Olympic Games [2]. This shows that diabetes should not be seen as a limitation to involvement in school activities, at work or in sports. Conditions that must be met include one's knowledge of self-control related to the disease, to be applied during physical exercise, and the ability to balance physical exertion with insulin intake and with proper diet [3].

\section{Health benefits gained from physical activity in type 1 diabetes}

Regular physical exercise is beneficial for diabetes control, at the same time reducing insulin demand. It also decreases the risk of hazardous late complications, such as cardiovascular diseases and arterial hypertension [4]. It directly affects the results of the therapy applied and the patient's well-being [5]. This is particularly important in view of the fact that cardiovascular diseases start earlier and occur 10 times more often in patients with diabetes than in healthy populations [6]. Disorders of this type most commonly begin approximately 15-20 years after the onset of diabetes. However, there is a risk that diabetic retinopathy or nephropathy may develop even in childhood; therefore, adequate preventive measures should be initiated as early as possible. The undesirable factors include such comorbid conditions as excessive body mass, obesity, arterial hypertension, poor glycaemic control, and dyslipidaemia, which frequently result from lack of physical activity [7].

Health-related benefits resulting from regular exercise in type 1 diabetes were described by Bohn et al. They reported evidence confirming that physical activity in type 1 diabetes reduces the risk of cardiovascular disorders and improves metabolic control, while also reducing the risk of diabetes-related complications [8]. Cuenca-García et al. demonstrated a strong relationship between moderate-intensity physical activity and a beneficial decrease in the level of $\mathrm{HbA}_{1 \mathrm{c}}$, which is of key importance in diabetes management [9].

Furthermore, regular physical activity improves the child's mental condition, which is reflected by higher self-esteem and better quality of life. Metlu et al. investigated psychological aspects of type 1 diabetes, and they suggested that children suffering from this condition are particularly at risk of depressive and anxiety disorders; they also confirmed that exercise is an important preventive factor [10].

\section{Recommendations}

As in the case of healthy children between 5 and 17 years of age, in accordance with WHO recommendations, children with diagnosed diabetes should perform moderate to vigorous physical activity (MVPA) for a minimum of 60 minutes per day. Any activity in excess of this norm will produce additional health-related benefits. It is also recommended that vigorous activity should be performed by children at least three days per week. [11]. The latest guidelines published in 2018 by the International Society for Paediatric and Adolescent Diabetes (ISPAD) point out that children (aged 5-11 years) and adolescents (aged 12-17 years) should perform physical activity for a minimum of 60 minutes per day, including vigorous physical activity for a minimum of 20 minutes, and they should minimise sedentary time each day [12]. Likewise, the recommendations of Diabetes Poland (Polish Diabetes Association) published in 2018 specify that in order to achieve the most effective diabetes control, physical activity should be undertaken each day, or for a minimum of 2-3 days per week. For the best effects, the proper activity should be preceded by 5-10 minutes of introductory warm-up, and it should be followed with calming activities, e.g. relaxing or stretching exercise [13].

\section{Contemporary methods of assessing physical activity}

Physical activity may be assessed by its four main aspects: frequency, intensity, amount, and type of activity (Table I).

Any energy expenditure of the body exceeding the value observed at rest is directly associated with the intensity of physical effort. Physical exertion can be classified according to the Borg scale, which distinguishes sedentary activity, light activity, moderate activity, and vigorous activity [17]. According to the $\mathrm{WHO}$, the greatest health-related benefits are gained from moderate to vigorous physical activity (MVPA). The MVPA index is calculated based on the Metabolic Equivalent of Task (MET). One MET corresponds to the energy expenditure of a person seated at rest, or it specifies oxygen consumption at approximately $3.5 \mathrm{ml} / \mathrm{min} / \mathrm{kg}$ b.w. The MET number shows how much more energy is used during a physical activity compared to the energy spent when seated at rest. MVPA requires energy expenditure ranging from 3 to 6 METs, leading to faster heart rate and shortness of breath. Examples of activities defined as moderate-intensity include: walking at brisk pace, dancing, gardening, performing housework, sports and games, and weightlifting $<20 \mathrm{~kg}$. The MVPA index is described in time units or as a percentage [14]. 
Table I. The main components of physical activity assessment [14-16]

Components of physical activity assessment

Frequency How often is physical activity performed, e.g. in an hour, day, week, month, etc. In data analysis the frequency tends to be classified based on the number of sessions (bouts) with a duration of $\geq 10 \mathrm{~min}$

\begin{tabular}{ll}
\hline Intensity & Categorisation based on Borg scale (Borg, 1982): sedentary behaviours; light, moderate, vigorous physical \\
& activity. It is measured using index rates: \\
& - metabolic equivalents of task (METs), the most common distinction: moderate physical activity between \\
& 3 and 6 METs, moderate intensity activity $>3$ METs and vigorous activity $>6$ METs \\
& - heart function, heart rate (HR) \\
\hline Amount & Assessment of number of hours/minutes; distance; number of steps in a given period of time/day, week, or month \\
\hline Type of & Categorisation of activity, e.g. watching TV, walking, doing sports, cleaning, gardening, napping, locomotion \\
activity & Categorisation as per domains of life, i.e. work, home environment, locomotion/change of place, leisure \\
& Categorisation into spontaneous or organised (scheduled) activity
\end{tabular}

Vigorous physical activity (VPA) is defined as activity requiring energy expenditure in excess of 6 METs, which leads to sweating, shortness of breath, and increased heart rate. As a rule, these are activities connected with sports, i.e. jogging, mountain climbing, aerobics, fast cycling, swimming, team games, and weightlifting $>20 \mathrm{~kg}$.

Daily number of steps also reflects the level of regular exercise. In accordance with criteria adopted by Tudor-Locke et al., the standard number of steps per day for boys is defined as 13,000-15,000 and for girls as 11,000-12,000. In their age-related analyses these authors suggest that teenagers over 12 years of age should perform from 10,000 to 11,700 steps/day, and for comparison, adults should perform from 7000 to 8000 steps/ day, depending on the gender, age, and health status. According to Tudor-Locke, an active adult walks 10,000-12,499 steps/ day, and a very active adults performs more than 12,499 steps per day. This norm has been commonly adopted. Likewise, Andrew et al. take into account steps per day to determine the level of physical activity, and they describe lifestyles as: non-active/ sedentary, when the number of daily steps does not exceed 5000; inactive from 5000 to 7499 steps; moderately active 75009999 steps; active from 10,000-12,500 steps; and very active when the number of daily steps exceeds 12,500 [18].

Currently a lot of studies focus on sedentary behaviours, i.e. those that do not involve movement and require very low energy expenditure (e.g. seated or lying position). Researchers analyse the related rates reflecting, e.g., the amount of time of inactivity (minutes/hours/\% of time per day), as well as the number and length of so-called sedentary breaks per day. Sedentary behaviours are most commonly assessed in the context of the following activities: watching TV, using such devices as computers, video game consoles, or phones, and time spent in a seated position at school/work, or during transport. Nowa- days, all of the above parameters can be assessed with high accuracy using advanced tools, which are described in the subsequent part of this chapter [19].

Methods applied to assess physical activity are based mainly on objective and subjective techniques (Table II).

\section{Subjective methods}

Subjective assessment is formulated based on the subject's personal perceptions related to the past or the present time. The tools applied during this type of study include questionnaires and physical activity diaries. The information acquired from these provide a general idea about physical activity performed in a given period, e.g. month, year, or during the entire lifetime. Their various types include global questionnaires, recall questionnaires related to the past, as well as those providing quantitative data (quantitative history).

Validation studies have shown that questionnaire-based assessments present the highest correlations with vigorous physical exercise that is scheduled and can be described by the respondent in terms of frequency and duration. This type of assessment is less reliable in the case of light, moderate, or moderately vigorous exercise, typical for spontaneous and everyday activities. It has been observed by specialists that surveys can mainly be used to classify groups of subjects as active or inactive, yet they will not provide objective measures for determining physical activity indexes. This suggests that studies based exclusively on this kind of method are significantly limited. Other options include Physical Activity Diaries/Logs, which for a defined period of time are regularly completed by subjects with hour-by-hour report of physical activity. The above methods may effectively supplement objective assessments [19]. 
Table II. Methods of assessing physical activity - tools and limitations [19]

\begin{tabular}{|c|c|c|}
\hline Methods & Tools & Limitations \\
\hline Subjective & $\begin{array}{l}\text { paper questionnaires } \\
\text { electronic questionnaires } \\
\text { physical activity diaries }\end{array}$ & $\begin{array}{l}\text { - of little use in children under } 10-11 \text { years old, who as a rule do not fill } \\
\text { in questionnaires without assistance and in a reliable way }\end{array}$ \\
\hline \multirow[t]{3}{*}{ Objective } & accelerometers & $\begin{array}{l}\text { - limited accuracy of measurement during cycling, swimming, } \\
\text { and weightlifting } \\
\text { - lack of feedback data continuously on display for the subjects }\end{array}$ \\
\hline & pedometers & $\begin{array}{l}\text { - lack of accurate measurement during jogging, cycling, swimming } \\
\text { - no data related to low-intensity activity and time during which the device } \\
\text { is switched off }\end{array}$ \\
\hline & heart rate monitors & $\begin{array}{l}\text { - poor reliability of data related to moderate and light physical activity } \\
\text { - measurement depending on multiple factors, such as age, emotions } \\
\text { - inconvenient for use during a long-term study } \\
\text { - the device alone is not sufficient to assess physical activity }\end{array}$ \\
\hline Observational & $\begin{array}{l}\text { real-life observation/video } \\
\text { recordings } \\
\text { double labelled water method } \\
\text { calorimetric method }\end{array}$ & $\begin{array}{l}\text { - reliability of measurement depends on the observers' assessment, } \\
\text { provided that they use uniform rules, definitions and interpretations as } \\
\text { well as methods of calculating data } \\
\text { - high risk of error } \\
\text { - it is difficult to compare varied results }\end{array}$ \\
\hline
\end{tabular}

\section{Objective methods}

Today there are many objective methods enabling highly accurate measurements of parameters reflecting the level of physical activity. These include all sorts of monitors with motion sensors, which are worn by the subject and continuously perform measurements of various factors, such as energy expenditure, duration or intensity of physical activity, as well as heart rate during exercise [20].

The most basic and also the most popular devices of this type, pedometers, constantly count the number of steps taken during walking or running, for the course of the entire study. The result can be viewed on an ongoing basis; therefore, it is believed pedometers motivate users to greater physical activity in their daily lives. From the standpoint of scientific research, measurements performed with pedometers pose many limitations. Although the device provides information on the frequency of physical activity, it does not measure intensity of physical exertion. Furthermore, pedometers are less accurate in counting steps walked at low speed, i.e. $<60 \mathrm{~m} /$ minute; hence, in the case of studies involving adults the results may be unreliable. Another drawback of pedometers lies in the fact that results may be falsified and increased, e.g. if the subject deliberately shakes the device, or by shocks which accompany driving a car; in such case the final count does not reflect the actual level of the subject's activity [15].

Currently accelerometers are the most accurate and objective motion detectors used in assessing physical activity. These devices detect acceleration in body motion, enabling reliable measurement of intensity and duration of physical activity, as well as number of steps and duration of non-activity (sedentary analysis). Parameters of motion are measured by a piezoelectric sensor, which transforms an analogue signal into a digital signal in the range of $0.1-3.6 \mathrm{~Hz}$. This enables highly accurate monitoring of subjects' physical activity [21].

The latest accelerometers can detect acceleration in all the three planes of motion, enabling more detailed motion analysis compared to pedometers. This is particularly important in studies involving children because the device records such activities as jumping or climbing. Information related to motion is measured by an accelerometer in the form of impulse counts, which are summarised in a defined unit of time, e.g. $1 \mathrm{~s}, 5 \mathrm{~s}, 15 \mathrm{~s}, 30 \mathrm{~s}$, minute epochs [22]. The sum of the impulses received is converted into information reflecting energy expenditure or intensity of physical activity, classified as very light, light, moderate, vigorous, or highly vigorous. Accelerometers as a rule are worn at the waist, attached with an adjustable strap [23]. 
It was demonstrated that they are highly reliable, provided that they are worn for an uninterrupted period of seven days, excluding the time of taking a bath and swimming pool activities. Many studies have emphasised numerous advantages of applying accelerometers in scientific research because they are objective, non-invasive, accurate, and convenient to use $[24,25]$

An accelerometer-based study may be supplemented with a measure of the frequency of contractions of the heart, increasing with more vigorous physical effort. Applied for this purpose, heart rate monitors are worn on the chest, and are optionally linked with a data receiver worn on the wrist. In analyses of heart rates associated with assessments of physical activity it is necessary to account for certain limiting factors, i.e. the subjects' age, body dimensions, and emotional condition because these affect the results measured. Therefore, analysis of exertion and heart rate frequently shows nonlinear correlations and is recognised as an indirect method [26].

\section{Summary}

Due to the fact that physical exertion leads to fluctuations in blood glucose levels, type 1 diabetes in the case of children and adolescents may potentially constitute a barrier for taking a sufficient amount of exercise on a daily basis. The problem may be exacerbated by fear of severe hypoglycaemia, which may occur not only during physical activity, but also up to 24 hours after training, due to increased insulin sensitivity. Those affected by the condition must maintain control over, e.g., the initial level of glycaemia, time of the previous injection, location of the injection, amount of food consumed, time of day, or type of exercise performed. Importantly, the response of the body to

\section{References}

1. Niewiadomska M, Radziejewska M, Horodnicka-Józwa A, Petriczko E. Agility in treatment of children with type 1 diabetes-pilot study. Pediatr Endocrinol Diabetes Metab 2010; 16: 89-93.

2. Robertson K, Riddell MC, Guinhouya BC, et al. Exercise in children and adolescents with diabetes. Pediatric Diabetes 2014; 15: 203223. doi: 10.1111/pedi.12176

3. Łuszczki E, Dereń K, Sobek G. Comparison of nutrition knowledge in patients with type 1 and type 2 diabetes. J Pre-Clinical Clin Res 2015; 1: 23-26. doi: 10.5604/18982395.1157571

4. Quirk H, Blake H, Tennyson R, et al. Physical activity interventions in children and young people with Type 1 diabetes mellitus: a systematic review with meta-analysis. Diabet Med 2014; 31: 1163-1173. doi: 10.1111/dme.12531

5. Edmunds S, Roche D, Stratton G, et al. Physical activity and psychological well-being in children with Type 1 diabetes. Psychol Health Med 2007; 12: 353-363. doi: 10.1080/13548500600975446

6. Martyn-Nemeth P, Schwarz Farabi S, Mihailescu D, et al. Fear of hypoglycemia in adults with type 1 diabetes: impact of therapeutic physical exertion varies from person to person, and this results in a need for self-control and for raising the child's awareness with regard to diabetes [27]. Because of all these factors, physical exercise poses a significant challenge not only to the child with diabetes but also for their parents, teachers, friends, and school mates who should know how to prevent hypoglycaemia occurring in the affected child [28]. Ryninks et al. suggests that, from the viewpoint of affected children's physical activity, poor awareness related to diabetes and lack of understanding displayed by teachers (including PE teachers) and peers may be a greater barrier than the fear of hypoglycaemia [29].

The most objective assessment of physical activity in children and adolescents is enabled by accelerometers, which detect velocity changes in all the three planes of motion and as a result allow accurate analysis of motor activity. Other available options include pedometers, heart rate monitors, as well as subjective methods applying standardised questionnaires.

Assessment of physical activity in children and adolescents with type 1 diabetes is of extreme importance because an active and healthy lifestyle is a precondition for their capacity to retain health for a long time, and it contributes to the effectiveness of the treatment administered [30]

\section{Conclusions}

Physical activity in type 1 diabetes contributes to the effectiveness of the treatment administered, i.e. exercise is beneficial for diabetes control and reducing insulin demand, and decreases the risk of hazardous late complications. The most objective assessment of physical activity in children and adolescents is enabled by accelerometers.

advances and strategies for prevention- a review. J Diabetes Complications 2016; 30: 167-177. doi: 10.1016/j.jdiacomp.2015.09.003

7. Miculis CP, Mascarenhas LP, Boguszewski MCS, de Campos W. Physical activity in children with type 1 diabetes. J Pediatr (Rio J) 2010; 86: 271-278. doi: 10.2223/JPED.2003.

8. Bohn B, Herbst A, Pfeifer M, et al. Impact of Physical Activity on Glycemic Control and Prevalence of Cardiovascular Risk Factors in Adults With Type 1 Diabetes: A Cross-sectional Multicenter Study of 18,028 Patients. Diabetes Care 2015; 38: 1536-1543. doi: 10.2337/dc15-0030

9. Cuenca-García M, Jago R, Shield JP, Burren CP. How does physical activity and fitness influence glycaemic control in young people with Type 1 diabetes? Diabet Med 2012; 29: 369-376. doi: 10.1111/j.1464-5491.2012.03740.x

10. Mutlu EK, Mutlu C, Taskiran H, Ozgen IT. Association of physical activity level with depression, anxiety, and quality of life in children with type 1 diabetes mellitus. J Pediatr Endocrinol Metab 2015; 28 : 1273-1278. doi: 10.1515/jpem-2015-0082

11. World Health Organization. Global strategy on diet, physical activity and health. Available from: www.who.int. Updated 15 May 2018 
12. Adolfsson P, Riddell MC, Taplin CE, et al. ISPAD Clinical Practice Consensus Guidelines 2018: Exercise in children and adolescents with diabetes. Pediatr Diabetes 2018; 19: 205-226. doi: 10.1111/ pedi.12755

13. Polskie Towarzystwo Diabetologiczne. Zalecenia kliniczne dotyczące postępowania chorych na cukrzycę 2018. Diabetol Prakt 2018; 4: 1-102.

14. Strath SJ, Kaminsky LA, Ainsworth BE. Guide to the assessment of physical activity: clinical and research applications a scientific statement from the American Heart Association. Circulation 2013; 128: 2259-2279. doi: 10.1161/01.cir.0000435708.67487.da

15. Hills AP, Mokhtar N, Byrne NM. Assessment of Physical Activity and Energy Expenditure: An Overview of Objective Measures. Front Nutr 2014; 1: 5. doi: 10.3389/fnut.2014.00005

16. Bauman, A, Phongsvan, P, Schoeppe S, Owen N. Physical activity measurement - a primer for health promotion. Promot Educ 2006; 13: 92-103.

17. Katch VL, McArdle WD, Katch FI. Energy expenditure during rest and physical activity. In: McArdle WD, Katch FI, Katch VL (ed.). Essentials of Exercise Physiology. 4th ed. Lippincott Williams \& Wilkins, Baltimore 2011; 237-262.

18. Tudor-Locke C, Craig CL, Beets MW, et al. How many steps/day are enough? for children and adolescents. Int J of Behav Nutr Phys Act 2011; 8: 78. doi: 10.1186/1479-5868-8-78

19. Sallis JF. Measuring Physical Activity: Practical Approaches for Program Evaluation in Native American Communities. J Public Health Manag Pract 2010; 16: 404-410. doi: 10.1097/PHH.0b013e 3181d52804

20. Sylvia LG, Bernstein EE, Hubbard JL. A Practical Guide to Measuring Physical Activity. J Acad Nutr Diet 2014; 114: 199-208. doi: 10.1016/j.jand.2013.09.018

21. Products. Actigraph wGT3X-BT [Internet]. Updated November 2016. Available at: www.actigraphcorp.com
22. Welk GJ. Use of accelerometry-based activity monitors to assess physical activity. In: Welk GJ (ed.). Physical Activity Assessments for Health-Related Research. Human Kinetics, Champaign 2002; 125-142.

23. Loprinzi PD, Cardinal BJ. Measuring children's physical activity and sedentary behaviuors. Cardinal Journal of Exercise Science \& Fitness 2011; 9: 15-23.

24. van Cauwenberghe E, Labarque V, Trost SG, et al. Calibration and comparison of accelerometer cutpoints in preschool children. Int JPediatr Obes 2011; 6: 582-589. doi: 10.3109/17477166.2010.526223

25. Barreira TV, Schuna JM, Tudor-Locke C, et al. Reliability of accelerometer-determined physical activity and sedentary behavior in school-aged children: a 12-country study. Int J Obes Suppl 2015; 5: 29-35. doi: 10.1038/ijosup.2015.16

26. Janz KF. Use of heart rate monitors to assess physical activity. In: Welk GJ (ed.). Physical Activity Assessments for Health-Related Research. Human Kinetics, Champaign 2002; 143-162.

27. Tobiaszewska M, Głowińska-Olszewska B, Bossowski A. Wiedza na temat cukrzycy i samokontroli a stosowanie zasad samokontroli w życiu codziennym u dzieci i młodzieży z cukrzycą typu 1. Endokrynol Ped 2011; 3: 39-48.

28. MacMillan F, Kirk A, Mutrie $N$, et al. Supporting participation in physical education at school in youth with type 1 diabetes: Perceptions of teachers, youth with type 1 diabetes, parents and diabetes professionals. European Physical Education Review 2015; 21: 3-30. doi:10.1177/1356336×14534367

29. Ryninks K, Sutton E, Thomas E, et al. Attitudes to Exercise and Diabetes in Young People with Type 1 Diabetes Mellitus: A Qualitative Analysis. PLoS One 2015; 10: e0137562. doi: 10.1371/journal. pone.0137562

30. Pivovarov JA, Taplin CE, Riddell MC, et al. Current perspectives on physical activity and exercise for youth with diabetes. Pediatr Diabetes 2015; 16: 242-255. doi: 10.1111/pedi.12272 